\title{
小角度断層撮影技法の検討
}

\author{
大阪医科大学放射線医学教室（主任 赤木弘炤教授） \\ 松村昭三・杉信義人・福森英雄
}

（論文受付 昭和 39 年 9 月 12 日）

\section{THE EXPERIMENTAL VALUATION OF RECTILINEAR TOMOGRAPHY AT SMALL ANGLES}

\author{
By SHOzO MATSUMURA \\ YOSHITO SUGINOBU \\ HIDEO FUKUMORI \\ Department of Radiology, Osaka Medi- \\ cal College. (Director Professor HIRO- \\ AKI AKAGI)
}

(Article received Sept. 12, 1964)

\section{Summary}

The valuation of tomographic technic at small angles utilizing rectilinear apparatus was carried out on account of numerical preponderance of this mode of the movement. A phantom was designed to attain moderate photographic contrast and its tomographic images were surveyed densitometrically. Several clinical cases also have been pursued. The application of rectilinear apparatus into this field is still regarded as practically worthwhile provided that appropriate objects and direction are selected from the viewpoint of neighbouring structures and supposes contrasting status.

\section{I. 緒言}

一般に行なわれている断層撮影技法では暈去能率を良 くするため, 管球振り角度を比較的大として奏施するこ とが多い.しかしとの場合には希望截断層内の陰影も管 球の移動に従ってその大きさをかなり変化しながらフィ ルム上に投影されて行くため, 撮影された像の鮮鋭度ひ いては対比度を著しく損われることになる。（第1図） 勿論との外に像質に影響する囚子としては管球焦点の大 きさ, 増感紙の鮮鋭度, 截断面フィルム間距離と焦点截 断面間距離の比率等が存在するが, 就中振り角度の影響 は少くないと考えられる. 従って振り角度をでく小とし て検査対象に重睤する陰影を適宜抹消し, しかす被検像 の鮮鋭度を増加する方式の検討が Waard, Lindblom 等
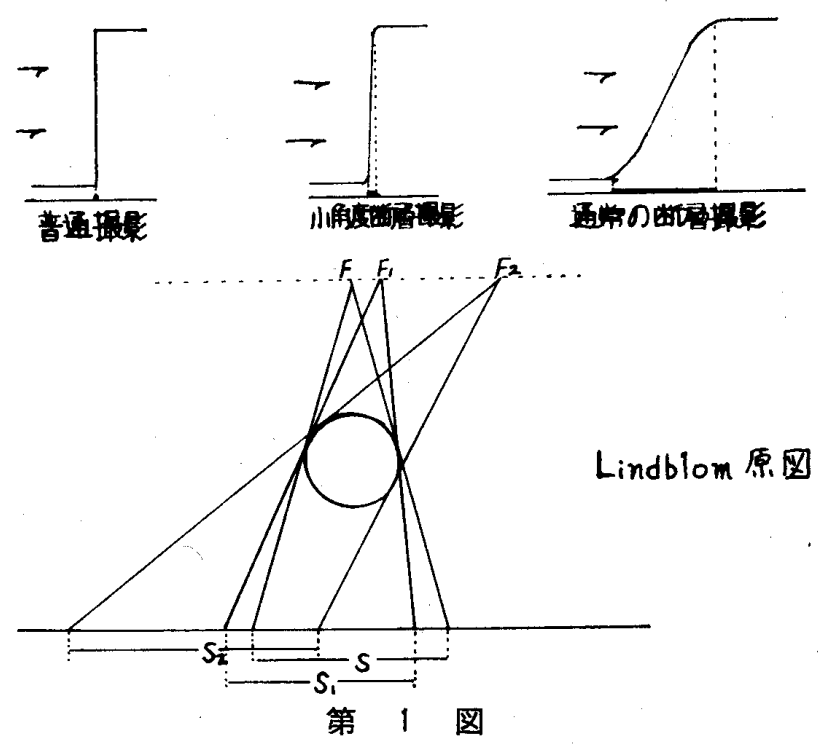
によって行なわれ，最近では Westraによってある程度 の愿さを有する截屏の像を普通撮影に準じて得る意味で の “Zonographie”として報告がなされている. 但しこ れ等諸家の考究において対象となっている装犆は主とし て多方式のあのである。それは一方向式装置においては 障害陰影や消去効率の方向性の影響が甚だしい点を考え れば当然の事と考えられる。しかしながら現在尚一方向 式装置の普及度が大きいととを考へ，本方式装置による 小角度断層撮影技法の導入可能性について実験的に検討 を行なった。

\section{II. 検討方法及び結果}

1. 使用 X線撮影装置について

使用断㬝撮影装置は島津 HL-5 型横形自動分割断㬝撮 影装置である.本装置は振り角度及び管球の移動速度が かなり広範囲にわたり調整可能であるが，振り角度の調 節は管球支持レヴアの運動により開閉する接点により電 気的に行なわれ，移動速度はギヤの組み合わせ変更に上 って行なっている.

2. 管球移動速度について

小角度断㬝撮影の実施に当たっては，X線発生装置の 容量と勘案して管球移動速度を適宣調整する必要のある 場合が多いと考えられる。

我々の採用している二種類の速度 $\mathrm{A}, \mathrm{B}$ 子振り角度,

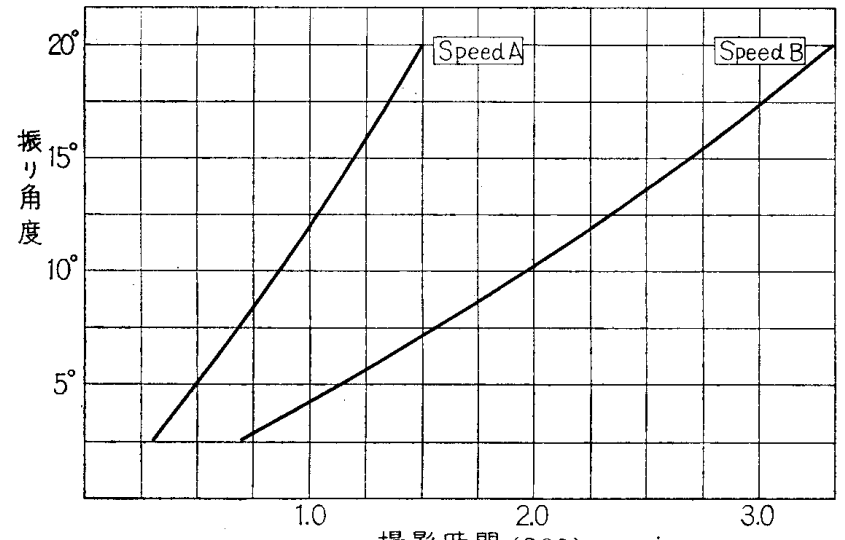

撮影間 (sec)

第 2 図

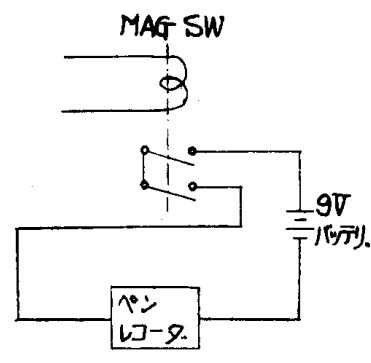

第 3 図
撮影時間測定回路は左に 示す如くで，回路が閉じら れるとその間レコーダは矩 形波を描く。したがって電 磁開閉器が働き, 一次回路 が閉じている間の通電時間 をペンレコーダに記録させ， 矩形波の長さ点求める。
撮影時間との相関を第 2 図に示した。例えば振り角度 $2.5^{\circ}$ として, 最む移動速度を遅くした場合は撮影時間と して 0.7 秒が得られている. 尚曝射時間の実測法として は, 第 3 图に示す如く一次回路の通電時間を乾電池とぺ ンレコーダを接続することにより計測している.

3. ファントム作成化ついて

実験に供したファントムの製作にあたっては，実際に 人体により X線像上に与えられるコントラスト状態が考 慮された。かかる点を勘案しないで検討を行なう時には ややあすれば実際に即しない結論を得るおえれがあるす のと思われた。 とくに小角度断風撮影像においては暉像 のつくるコントラスト状態の变化を人体 $\mathrm{X}$ 線像に打汁る 如く moderate な状態で観察して行く必要がある. 従う てファントムにおいてす著明なコントラストをなす金属 材料等のみによって構成することは必ずしも得策とは考 えられない。第 4 図に我々の使用したファントムの構成 について示したが，金属線以外に水溶性造影剤を種々の 濃度に稀釈して配置することにより所期の目的を達せし むる様汇試みたすのである。なお実際の撮影汇際しては $5 \mathrm{~cm}$ 厚のパラフィンブロック間汇はさんで用いた。

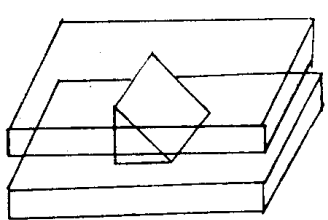

A. ヒューズ $1.0 \mathrm{~mm} \phi$

B. " $0.7 \mathrm{~mm} \phi$

C. ビニール管 $\left\{\begin{array}{l}\text { 外径 } 3.5 \mathrm{~mm} \\ 2.5 \mathrm{~mm}\end{array}\right.$ ウロコリン $\mathrm{M} 60 \% 3$ 倍稀 釈液

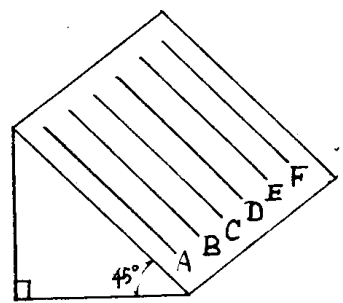

第 4 図
D.ビニール管 ウロコリン $\mathrm{M} 60 \% 4$ 倍稀 䣋液

E.ビニール管 ウロコリン $\mathrm{M} 60 \% 5$ 倍稀 秎液

F．木綿糸 $0.5 \mathrm{~mm} \phi$ ウロコリン $\mathrm{M} 60 \% 3$ 倍稀 粎液に浸して乾燥したも の
4.ファントムX線像の処理について

一般に曖昧コントラスト状態の変化様相を完全に定量

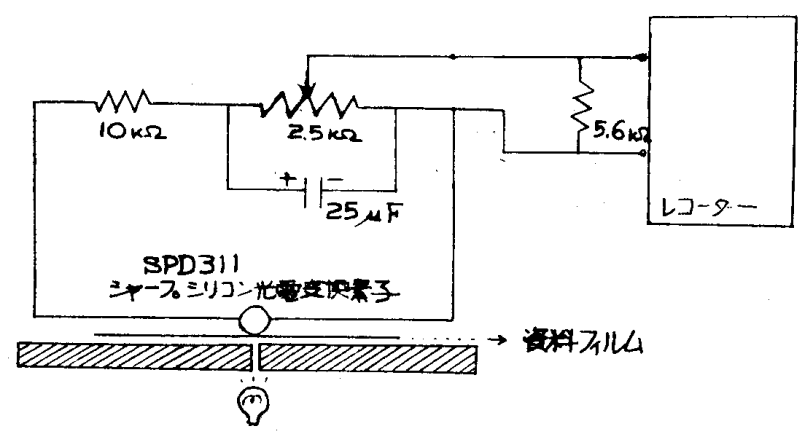

第 5 図 
的に検討するととはやや困難が伴うととが考えられるの で, 本研究にに㧍いては各X線像につき濃度曲線を描記 するととによってその傾向如何を把握しようと試みた。 描記機構としては回路図（第 5 図）に示す様に光電変 換素子よりの出力をペンレコーダに入れるととによって 行なった。
5. 濃度曲線群の解析

かくして得られた濃度曲線群（第6 図以下）を通覧す ると，各振り角度当たりの素地濃度が必ずしむ同一にな らないためにその絶対值においてやや差を生じたが，被 検物質の如何によって断風像のコントラスト状態はもち ろん, さらに截断面より離されるに従っての軍像の様相
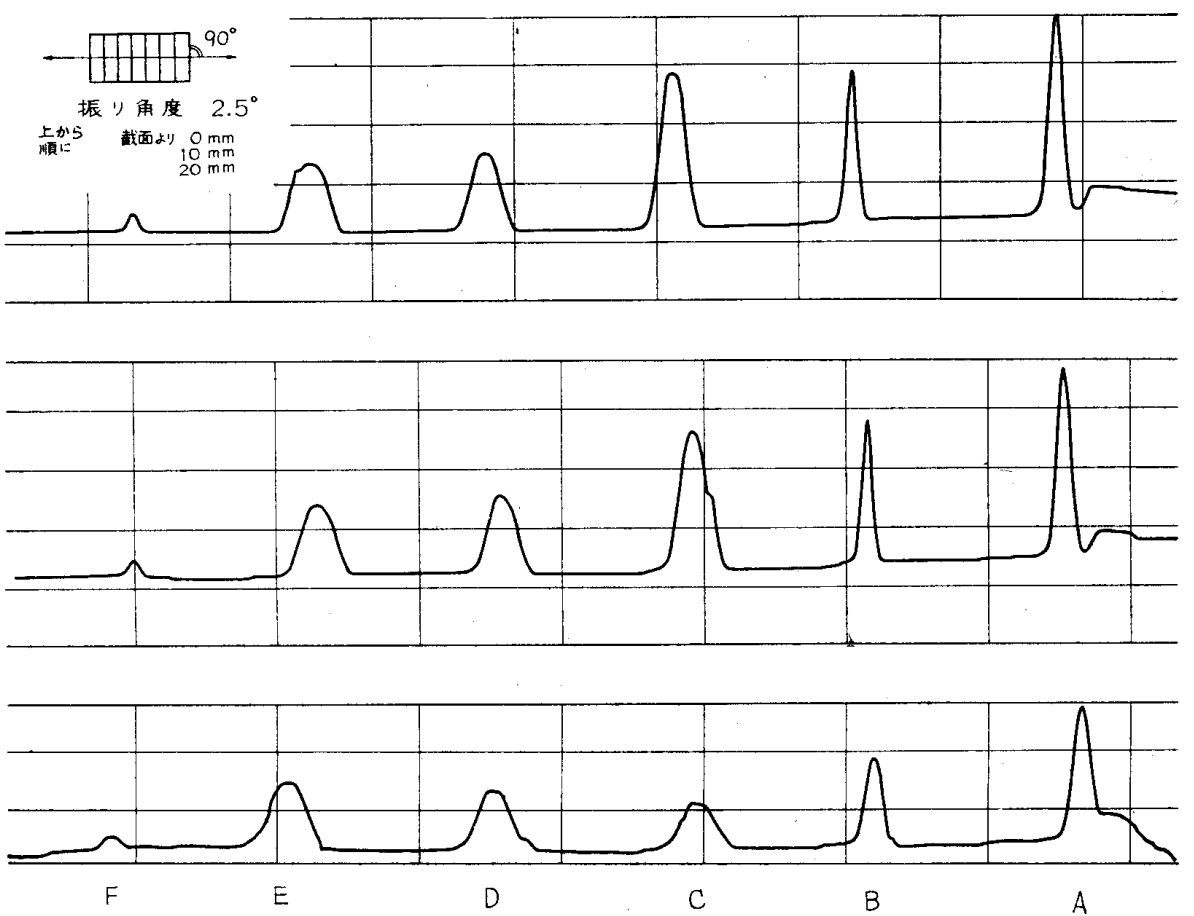

第 6 図
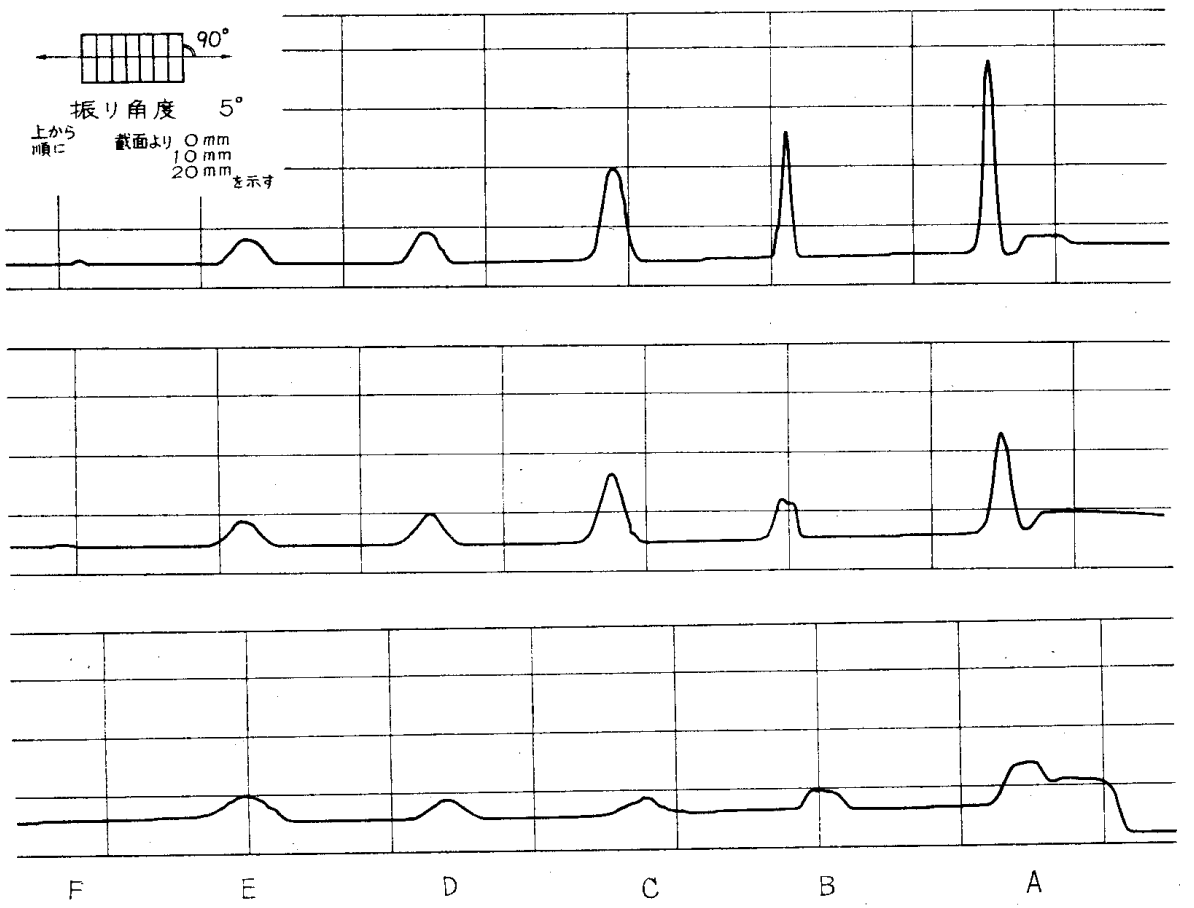

第 7 図 

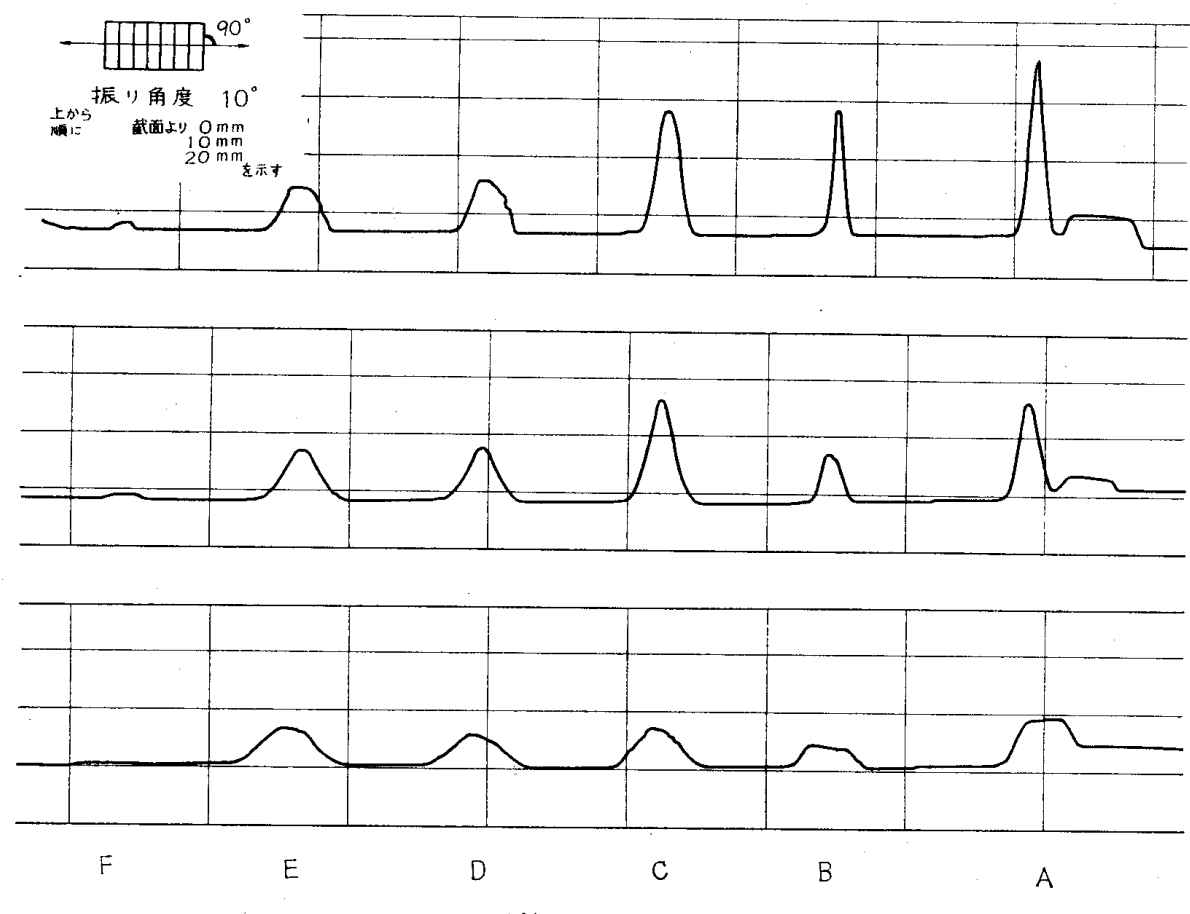

第 8 図
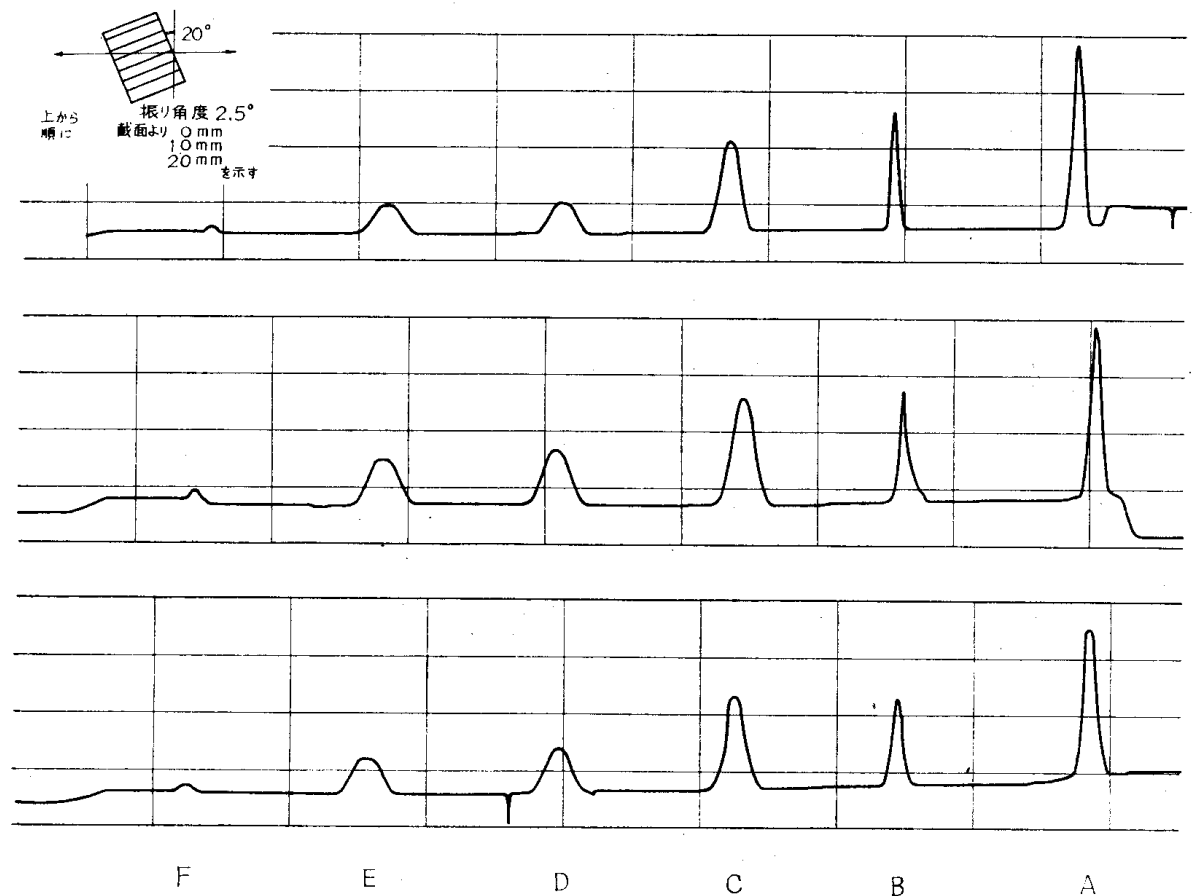

第 9 図

が一様に取扱えないのが観取される．即ちコントラスト の形成が比較的弱い場合はわづかな振り角度によっても その影響が甚だしく現われて来る。第6，7，8図はいつ れもファントム軸を管球軌道に対して直角に位置させた 場合で, blurringは当然著明になっているが，第 9 図の ようにファントム軸が管球軌道に対して $20^{\circ}$ とかなり平
行に近く位置せしめた場合でも被検像コントラストの弱 い場合は変化を無視できない。こはれまた，ある程度の 嬮さをむった被写体について，所謂 zonographic な概 念に基づいて，できるだけ鮮明な像を求める場合には， 振り角度もやはり極力小さく選ばれるべきであろう事を 示している. 


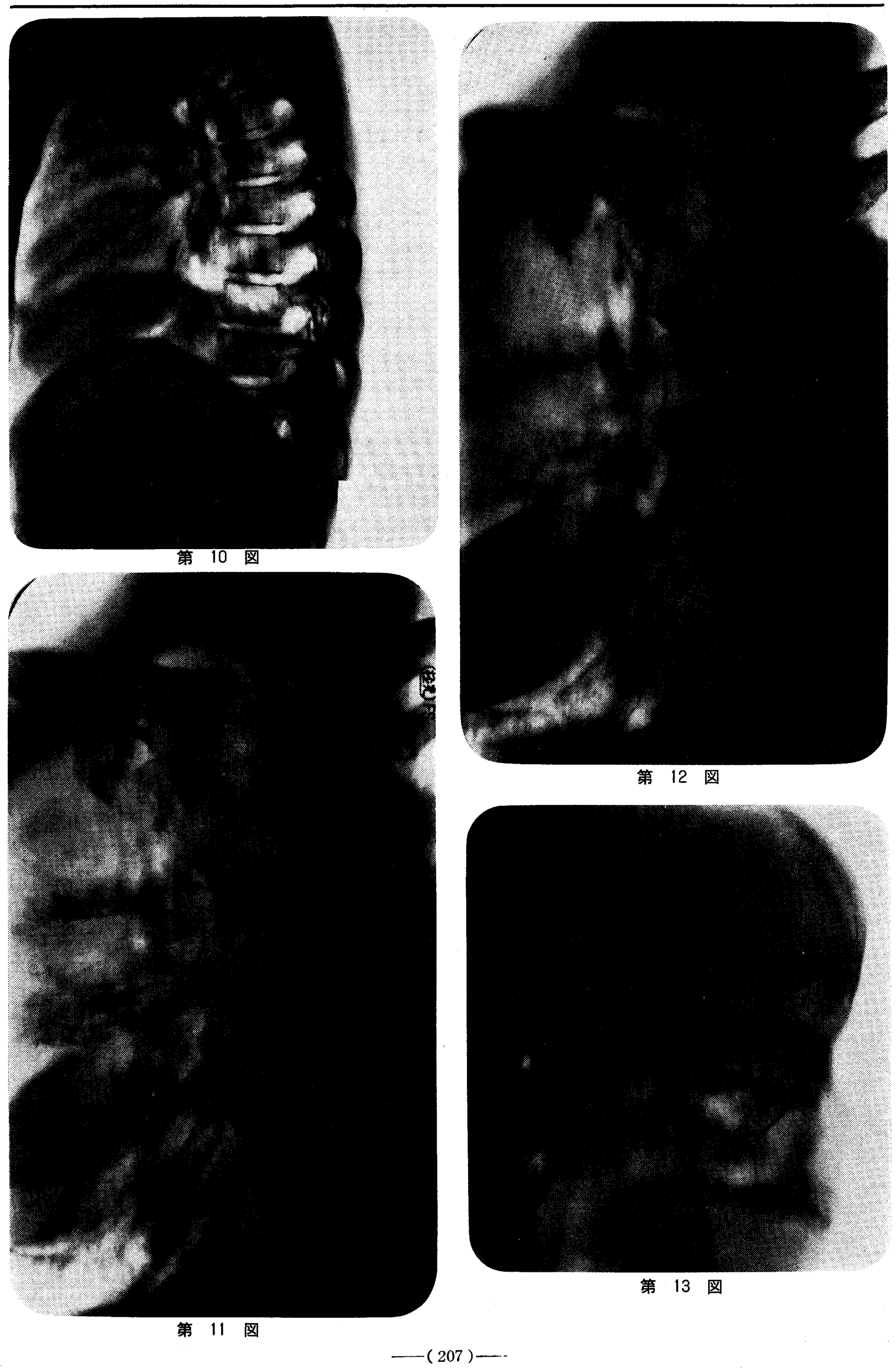


6. 臨床例についての検討

小角度断㬝撮影法によった胸推側面撮影は重疊する肋 骨陰影や肺内陰影を適宜抹消して，読影を便とするため に従来よりあやや試みられているが，上述の事実に徴し てあ振り角度はごく小とするように努められなければな らない.一方向式装置によってもそれは可能と考えられ る.（第10図）第11図は前胸壁に膿瘍を形成していた症 例であって，本撮影技法によって胸骨柄に骨萎縮像のあ るのが分る。

とくに小角度断層撮影像では普通撮影像之同様, 骨梁 像は殆ど暈けなくてすむのでその状態がよく分る。また 第12図は同一体位のままで截面高を変更して胸骨体部を 重点的に撮影したものである。 また本撮影技法は下顎骨 等の一側を側面像のまま左右重量させることなく観察で きる可能性が指摘できる．第13図に正常例及び下顎骨折 を疑われた顎関節前方脱囦例を示した。

\section{III. 結論}

以上の如く被検体の周囲構造如何や管球移動方向を適 宜勘案して丰施すれば，一方向式断風撮影装置を用いた 微小振り角度による断層撮影技法の応用される余地は実 用的な面上りみても充分に存在するものと考えられる。
終りに種々御指導を頂いた本学放射線医学教室赤木弘 昭教授に深く感謝の意を表する。（本論文の要旨は第23 回日本医学放射線学会総会及び第20回日本放射線技術学 会総会において発表した）

\section{References}

Cova, P. L., G. Pompili : Tomografia a strate spesso, Radiol. med. 43 (1957).

Lindblom, K. : On microtomography, Acta radiol. 42 (1955) ; Rotation tomography at small angles, Acta radiol. 43 (1955).

Pignataro, E. : Schichtaufnahme mit dicker und dunner Schicht bei vielfacher Strahlenrichtungsveranderung, Fortschr. Rontgenstr. 94 (1961).

Waard, R. H. de : Planigrafie met weinig vervaging, Ned. T. Geneesk 90 (1946).

Westra, D. : Zonographie, die Tomographie mit sehr geringer Verwischung. Fortschr. Rontgenstr. 97 (1962).

啮谷慶一郎：渡辺層 小角度断首撮影について. (日放技 会総会）15回. 